Agriculture, Agribusiness and Biotechnology

Vol.59: e16160586, January-December 2016 http://dx.doi.org/10.1590/1678-4324-2016160586 ISSN 1678-4324 Online Edition

BRAZILIAN ARCHIVES OF BIOLOGY AND TECHNOLOGY

AN INTERNATIONAL JOURNAL

\title{
Effects of organic fertilizers on the growth and yield of bush bean, winged bean and yard long bean
}

\author{
Mohammad Aminul Islam ${ }^{1}$, Amru Nasrulhaq Boyce ${ }^{1}$, Md Motior Rahman², Mohd Sofian \\ Azirun ${ }^{1}$ and Muhammad Aqeel Ashraf ${ }^{3,4 *}$. \\ ${ }^{1}$ Institute of Biological Sciences, Faculty of Science, University of Malaya Kuala Lumpur, Malaysia; ${ }^{2}$ Department \\ of Plant Agriculture, Crop Science Building, University of Guelph, 50 Stone Road E. Guelph, Ontario, Canada, \\ NIG 2W; ${ }^{3}$ Faculty of Science and Natural Resources, University Malaysia Sabah 88400 Kota Kinabalu, Sabah, \\ Malaysia; ${ }^{4}$ Department of Environmental Science and Engineering, School of Environmental Studies, China \\ University of Geosciences, 430074 Wuhan, P. R. China.
}

\begin{abstract}
VC (20\%), TC (20\%) and N:P:K fertilizer (farmer's practice) were used to determine the growth and yield attributes of bush bean (Phaseolus vulgaris), winged bean (Psophocarpus tetragonolobus) and yard long bean (Vigna unguiculata). Plants grown with VC (20\%) produced the highest fresh biomass for bush bean $\left(527.55 \mathrm{~g} \mathrm{~m}^{-2}\right)$, winged bean (1168.61 $\left.\mathrm{g} \mathrm{m}^{-2}\right)$ and yard long bean $\left(409.84 \mathrm{~g} \mathrm{~m}^{-2}\right)$. In all the tested legumes the highest pod weight, pod number, pod dry weight and pod length were found in the VC (20\%) treatment. Photosynthetic rates in the three legumes peaked at pod formation stage in all treatments, with the highest photosynthetic rate observed in winged bean $\left(56.17 \mu \mathrm{mol} \mathrm{m} \mathrm{s}^{-1}\right)$ grown with $\mathrm{VC}(20 \%)$. The highest yield for bush bean $\left(2.98\right.$ ton ha $\left.{ }^{-1}\right)$, winged bean (7.28 ton $\left.\mathrm{ha}^{-1}\right)$ and yard long bean (2.22 ton $\left.\mathrm{ha}^{-1}\right)$ were also found in VC (20\%) treatment. Furthermore, protein content was highest in bush bean $(26.50 \mathrm{~g} / \mathrm{lo0g})$, followed by yard long bean $(24.74 \mathrm{~g} / 100 \mathrm{~g})$ and winged bean $(22.04 \mathrm{~g} / 100 \mathrm{~g})$, under VC (20\%) treatment. It can be concluded that legumes grown with VC (20\%) produced the highest yield and yield attributes.
\end{abstract}

Key words: Vermicompost, compost, Phaseolus vulgaris, Psophocarpus tetragonolobus and Vigna unguiculata, photosynthesis, protein content

*Authors for correspondence: amru@um.edu.my 


\section{INTRODUCTION}

Beans are globally important leguminous vegetables that has been used for several centuries (Brink \& Belay, 2006) as food for humans and feed for animals (Amira et al. 2003). These plants originated from the Americas but is now cultivated all over the world due to its nutritional and culinary values. Furthermore beans contain high amounts of protein and vitamins (Valdez-Perez et al. 2011). Among all the beans, yard long bean, winged bean and bush bean are popular in Malaysia because of their distinctive and appetizing taste (Rahman et al. 2013; Marlene and Valio, 1996). Amongst the three, bush bean and winged bean have shown great potential for their productivity and popularity (Kara et al. 2009; Harvest, 2006)

For the production of these tropical legume vegetables apposite quantities of nutrients are needed for their growth and development. Otherwise physiological deficiency symptoms can occur (Takahashi, 1981). Over the years inorganic fertilizers have been widely used worldwide to support and optimize the growth of these vegetables. However, the use of organic fertilizer has gained more importance globally in the last few decades, due to efforts made for the conservation of agriculture. Organic fertilizers have been shown to help preserve natural resources and reduce degradation of ecosystem (Mäder et al. 2002; Francis and Daniel, 2004). As a result organic agriculture has become an alternative technology which encourages the use of natural organic compounds such as plant residues, manure, mulch and compost (Shannon et al. 2002). Application of these natural organic compounds have been shown to improve the soil nutritional state and as well as influencing other soil properties, such as aeration, water holding capacity and particles aggregation (Pagliai et al. 2004), which contribute for better crop production, even with the use of little or without fertilizer application.

Most vegetable producers use inorganic fertilizers for better production due to its easy and rapid availability to plants (Thy and Buntha, 2005). However the enduring use of synthetic fertilizers can eventually damage the soil chemical, physical and biological properties (Albiach et al. 2000). Organic fertilizers, on the other hand, provide beneficial effects to the soil and also increase availability of nutrients, which helps to maintain the quality and yield of crops and are less expensive than inorganic fertilizers (Thy and Buntha, 2005). Organic fertilizers are not only the source of organic matter and nutrient, but also boost microbial population, physical, biological and chemical properties of the soil (Albiach et al. 2000). Among organic fertilizers, compost and vermicompost are well known sources of plant nutrients (Sheata and El-Helaly, 2010 and Manivannan et al. 2009). Compost and vermicompost are soil conditioners, which provides nutrients and organic matter within the soil and also ameliorate the water-holding capacity, firmness and structure of soil (Vogtmann et al. 1993; Giusquiani et al. 1995; Diez and Krauss, 1997; Wells et al. 2000). They can improve the physical, chemical and biological properties of degraded or low fertility soil and also be the source of $\mathrm{N}, \mathrm{P}$ and $\mathrm{K}$ for plants (Baziramakenga and Simard, 2001). It has also been reported that application of compost in soil decrease disease incidence (root rot of beans) and produce vigorous plants (Cespedes et al. 2006). Although organic crop production is not a new idea, there is insufficient information regarding the organic cultivation of yard long bean and winged bean. In this an attempt is made to evaluate the effects of vermicompost and compost on productivity of yard long bean, winged bean and bush bean.

\section{MATERIALS AND METHODS}

\section{Soil management, seed germination and Experimental design}

Experiments were carried out at the greenhouse of the Institute of Biological Sciences, Faculty of Science, University of Malaya, Kuala Lumpur $\left(3^{\circ} 7^{\prime} 25^{\prime \prime N}, \quad 101^{\circ} 39^{\prime} 11^{\prime \prime E}\right), \quad$ Malaysia during September, 2013 to February 2014. Clay loam soil was collected from a nursery nearby and homogenized to a fine texture and removing inert matter before being used for growing the leguminous vegetables. Yard long bean, Winged bean and bush bean were grown in plastic pots of area size $0.245 \mathrm{~m}^{2}$. For preparing VC $(20 \%)$ and TC (20\%), $8 \mathrm{~kg}$ of air dried soil was mixed with 2 $\mathrm{kg}$ vermicompost and traditional compost. Ten kilogram of soil with $\mathrm{N}: \mathrm{P}: \mathrm{K}$ mixed fertilizer at the 
rate of $4.66 \mathrm{~g}$ per pot (mixed fertilizer at the rate of $190 \mathrm{~kg} \mathrm{ha}^{-1}$ i.e. $22-22-42 \mathrm{~kg} \mathrm{ha}^{-1}$ of $\mathrm{N}, \mathrm{P}_{2} \mathrm{O}_{5}, \mathrm{~K}_{2} \mathrm{O}$ respectively) was considered as control treatment or farmer's practice (FP). Four seeds of each legume (yard long bean, winged bean and bush bean) were sown in each pot. After germination two vigorous seedlings were selected for growth in each pot. Nine replications of each treatment was arranged in a completely randomized design (CRD).Watering was done every evening until completion of the experiment.

\section{Data collection}

Photosynthetic rate was recorded from randomly selected five leaves per plants using a Field Scout Quantum Meter (Spectrum Technologies, Inc.
Item\#3415F) at pre-flowering stage, flowering stage and pod formation stage. Number of pod and fresh pod weight was recorded after harvesting of the mature pods. Single pod weight was calculated by dividing total pod weight by the total number of pods per plant. Long bean and bush bean were harvested at 60 days while winged bean was harvested at 90 days due to their growth period variation. Plant height was recorded by using a measuring tape, while fresh biomass was determined using a weight scale. After harvest the number of active nodules in each plant was also recorded. Plant parts were oven dried at $70^{\circ} \mathrm{C}$ for 48 hours for dry weight determination. Percent dry matter of pod and biomass was calculated using the following formula;

\section{Dry weight (pod or biomass) X 100}

Percent dry matter $($ pod or biomass $)=$

\section{Protein Determination}

For the proximate composition of dry matter (method 934.01) and crude protein (method 968.06), analysis were carried out according to the official method of analysis of AOAC (AOAC, 2005).

\section{Statistical analysis}

Statistical analysis was carried out by one-way ANOVA using STAR (version 1.1 2013, biometrics and breeding informatics, PBGB division, International Rice Research Institute, Los Baños, Laguna) to evaluate the significant differences among means of all tested parameters at $95 \%$ level of confidence. Further statistical validity of the differences among treatment means were estimated using the Least Significance Difference (LSD) method.

\section{RESULTS}

As shown in Table 1, plant biomass was affected significantly by the treatment variables. Winged bean grown with VC (20\%) produced the highest total biomass and dry biomass. A similar trend was also observed in both bush bean and long bean when grown with VC (20\%).

For bush bean, total plant height was the highest $(314.19 \mathrm{~cm})$ in VC $(20 \%)$ treated plants and the lowest $(160.24 \mathrm{~cm})$ in the FP. Similarly for winged bean, the highest $(259.93 \mathrm{~cm})$ plant height was
Fresh weight (pod or biomass)

observed in VC (20\%) treatment and the lowest $(177.88 \mathrm{~cm})$ in FP plants. In yard long bean, the highest $(72.87 \mathrm{~cm})$ total height was seen in $\mathrm{VC}$ $(20 \%)$ treatment and the lowest $(47.89 \mathrm{~cm})$ in plants treated following the farmer's practice (FP) method (Table 1).

Number of nodules per plant in each legume vegetable was affected significantly by the treatment variables. Nodule number in bush bean was highest (28.33) in VC (20\%) treatment and lowest (18.56) in FP treatments. Similarly for both winged and long beans, the highest nodule number, 12.33 for winged bean and 33.33 for long bean was observed in VC $(20 \%)$ treatments. The lowest, for winged bean (6.67) and long bean (17.22) was seen in the FP plants (Table 1).

With regard to pod weight, the three legumes showed significant differences when grown in three different treatments. Bush bean grown in VC (20\%) produced the highest pod weight $(298.12$ $\mathrm{g} / \mathrm{m}^{2}$ ), with a minimum of $83.46 \mathrm{~g} / \mathrm{m}^{2}$ observed in the FP treatment. A similar trend was also observed in winged bean and yard long bean (Table 2).

Bush bean grown with VC (20\%) produced the highest number of pods (58.93) compared to 22.20 recorded in the FP treatment. A similar pattern was recorded in winged bean with a maximum number of pods of 44.00 and long bean with 20.86 in plants grown in VC (20\%). The lowest pod number was 24.94 for winged bean and 10.45 for 
long bean plants, grown under control conditions (Table 2).

Pod dry weight in bush bean was highest $(26.12 \mathrm{~g}$ $\left.\mathrm{m}^{-2}\right)$ in VC $(20 \%)$ treated plants and lowest $(6.12 \mathrm{~g}$ $\mathrm{m}^{-2}$ ) in the FP treatment. In winged bean the highest pod dry weight $\left(77.02 \mathrm{~g} \mathrm{~m}^{-2}\right)$ was recorded in VC $(20 \%)$ whilst the lowest $\left(23.83 \mathrm{~g} \mathrm{~m}^{-2}\right)$ was in FP treatment and similarly in the case of yard long bean as well (Table 2).

Analogously single pod weight was highest in the VC (20\%) treatments compared to the FP treatment for bush bean, winged and long beans with the highest recorded values of $5.09 \mathrm{~g}, 16.56 \mathrm{~g}$ and $10.81 \mathrm{~g}$, in that order. The lowest values observed were $3.76 \mathrm{~g}, 11.99 \mathrm{~g}$ and $9.60 \mathrm{~g}$ in the same order (Table 2).

With regard to pod length, bush bean, winged and long beans recorded highest values of $10.76 \mathrm{~cm}$, $22.27 \mathrm{~cm}$ and $30.00 \mathrm{~cm}$ respectively in VC (20\%) treatment followed by compost and control treatment. Again as with the other yield parameters above the shortest pod length were observed in FP treated plants with $7.89 \mathrm{~cm}$ for bush bean, $16.54 \mathrm{~cm}$ for winged beans and 21.56 $\mathrm{cm}$ for long bean (Table 2).

To see whether the VC (20\%) and TC (20\%) treatments affected photosynthesis in the legume plants, the photosynthetic rate was determined using a Field Scout Quantum Meter. As can be seen in Table 3, the photosynthetic rates in the legumes grown in VC $(20 \%)$ and TC $(20 \%)$ varied significantly from the FP treated plants. However no significant difference was observed between VC $(20 \%)$ and TC (20\%) treatments. During pre flowering, flowering and pod formation stage, the photosynthetic rate in winged bean, bush bean and yard long bean was highest in the VC (20\%) treated plants, followed by TC $(20 \%)$ treated plants and the lowest in the FP treated plants. In all treatments the photosynthetic rate was highest at pod formation stage and the highest rate of 56.17 $\mu \mathrm{mol} \mathrm{m} \mathrm{m}^{-2}$, was observed in winged bean grown in VC (20\%) (Table 3).

With regard to yield, bush bean, winged bean and yard long bean varied significantly in the three different treatments. In all the three crops, VC (20\%) (bush bean: 2.98 ton ha ${ }^{-1}$; winged bean: 7.28 ton ha ${ }^{-1}$; yard long bean: 2.22 ton $\mathrm{ha}^{-1}$ ) provided the best results followed by TC (20\%) treatment (bush bean: 1.45 ton $\mathrm{ha}^{-1}$; winged bean: 5.06 ton $\mathrm{ha}^{-1}$; yard long bean: 1.58 ton $\mathrm{ha}^{-1}$ ) and FP treatment (bush bean: 0.83 ton $\mathrm{ha}^{-1}$; winged bean: 2.97 ton $\mathrm{ha}^{-1}$; yard long bean: 0.85 ton $\mathrm{ha}^{-1}$ ). Among the three crops, winged bean showed the best performance (Table 4).

With regard to nitrogen, an important major element or macronutrient in plants, found in molecules such chlorophyll, amino acids, proteins and nucleic acids, the nitrogen percentage in the three crops was best in the VC $(20 \%)$ treatment than in TC (20\%) and FP treated plants. In bush bean, the nitrogen percentage was highest $(4.24 \%)$ in VC (20\%) treatment, followed by winged bean $(3.53 \%)$ and long bean $(3.96 \%)$. The lowest values were observed in control plants (Table 4).

An important ingredient in vegetables is protein which is an important dietary element apart from being important in situ, as one of the major proteins in leaves is the photosynthetic enzyme, Rubisco, which can amount to $25-50 \%$ of the leaf's protein. As shown in Table 4, the amount of protein, as determined by the Kjeldahl method, in bush bean, winged bean and yard long bean varied significantly between the VC (20\%), TC (20\%) and FP plants. No significant difference was observed between TC (20\%) and FP or control plants. It was highest in bush bean, where the amount of protein in mature pods was 26.50 $\mathrm{g} / 100 \mathrm{~g}$ in VC $(20 \%)$ treatment. In the case of winged and long beans, the highest protein content recorded was $22.04 \mathrm{~g} / 100 \mathrm{~g}$ and $24.74 \mathrm{~g} / 100 \mathrm{~g}$ in VC (20\%). The control or FP plants recorded the lowest protein content values.

Table 1: Fresh Biomass $\left(\mathrm{g} \mathrm{m}^{-2}\right)$, Total dry Biomass $\left(\mathrm{g} \mathrm{m}^{-2}\right)$, Plant Height $(\mathrm{cm})$ and nodule number of Bush bean, Winged bean and Yard long bean

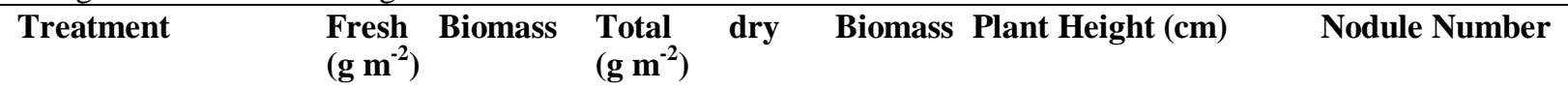

\begin{tabular}{lllll}
\hline Bush Bean & & & & \\
VC $(20 \%)$ & $527.55 \mathrm{a}$ & $60.41 \mathrm{a}$ & $314.19 \mathrm{a}$ & $28.33 \mathrm{a}$ \\
TC $(20 \%)$ & $255.67 \mathrm{~b}$ & $24.98 \mathrm{~b}$ & $263.98 \mathrm{~b}$ & $25.67 \mathrm{~b}$ \\
FP & $168.41 \mathrm{c}$ & $13.27 \mathrm{c}$ & $160.24 \mathrm{c}$ & $18.56 \mathrm{c}$ \\
\hline
\end{tabular}




\begin{tabular}{|c|c|c|c|c|}
\hline \multicolumn{5}{|c|}{ Winged Bean } \\
\hline VC $(20 \%)$ & $1168.61 \mathrm{a}$ & $174.49 \mathrm{a}$ & $259.93 \mathrm{a}$ & $12.33 \mathrm{a}$ \\
\hline TC $(20 \%)$ & $864.49 \mathrm{~b}$ & $125.42 \mathrm{~b}$ & $233.91 \mathrm{~b}$ & $9.11 \mathrm{~b}$ \\
\hline FP & $429.51 \mathrm{c}$ & $52.04 \mathrm{c}$ & $177.88 \mathrm{c}$ & $6.67 \mathrm{~b}$ \\
\hline \multicolumn{5}{|c|}{ Yard Long Bean } \\
\hline VC $(20 \%)$ & $409.84 \mathrm{a}$ & $46.00 \mathrm{a}$ & $72.87 \mathrm{a}$ & $33.33 \mathrm{a}$ \\
\hline TC $(20 \%)$ & $298.44 \mathrm{~b}$ & $31.63 \mathrm{~b}$ & $60.31 \mathrm{ab}$ & $21.22 \mathrm{~b}$ \\
\hline FP & $172.49 \mathrm{c}$ & $14.00 \mathrm{c}$ & $47.89 \mathrm{~b}$ & $17.22 \mathrm{c}$ \\
\hline
\end{tabular}

Means followed by the same letters are not significantly different for each treatment means at the 0.05 by LSD,

Table 2: Pod weight $\left(\mathrm{g} \mathrm{m}^{-2}\right)$, Number of pod $\left(\mathrm{m}^{-2}\right)$, pod dry weight $\left(\mathrm{g} \mathrm{m}^{-2}\right)$, Single pod weight $(\mathrm{g})$ and Pod length $(\mathrm{cm})$ of Bush bean, Winged bean and Yard long bean

\begin{tabular}{|c|c|c|c|c|c|}
\hline Treatment & $\begin{array}{l}\text { Pod weight } \\
\left(\mathrm{g} \mathrm{m}^{-2}\right)\end{array}$ & $\begin{array}{l}\text { Number of } \\
\text { pod } \mathrm{m}^{-2}\end{array}$ & $\begin{array}{ll}\text { Pod } & \text { Dry } \\
\text { weight } & \\
\left(\mathrm{g} \mathrm{m}^{-2}\right) & \\
\end{array}$ & $\begin{array}{l}\text { Single Pod } \\
\text { Weight (gm) }\end{array}$ & $\begin{array}{ll}\text { Pod } & \text { length } \\
(\mathrm{cm}) & \end{array}$ \\
\hline \multicolumn{6}{|l|}{ Bush Bean } \\
\hline VC (20\%) & $298.12 \mathrm{a}$ & $58.93 \mathrm{a}$ & $26.12 \mathrm{a}$ & $5.09 \mathrm{a}$ & $10.76 \mathrm{a}$ \\
\hline TC $(20 \%)$ & $145.67 \mathrm{~b}$ & $34.94 \mathrm{~b}$ & $10.57 \mathrm{~b}$ & $4.23 \mathrm{a}$ & $9.87 \mathrm{a}$ \\
\hline FP & $83.46 \mathrm{c}$ & $22.20 \mathrm{c}$ & $6.12 \mathrm{~b}$ & $3.76 \mathrm{~b}$ & $7.89 \mathrm{~b}$ \\
\hline \multicolumn{6}{|l|}{ Winged Bean } \\
\hline VC $(20 \%)$ & $728.69 \mathrm{a}$ & $44.00 \mathrm{a}$ & $77.02 \mathrm{a}$ & $16.56 \mathrm{a}$ & $22.27 \mathrm{a}$ \\
\hline TC $(20 \%)$ & $506.85 \mathrm{~b}$ & $37.18 \mathrm{~b}$ & $46.78 \mathrm{~b}$ & $13.61 \mathrm{~b}$ & $19.11 b$ \\
\hline FP & 296.86 c & $24.94 \mathrm{c}$ & $23.83 \mathrm{c}$ & $11.99 \mathrm{c}$ & $16.54 \mathrm{c}$ \\
\hline $\begin{array}{l}\text { Yard Long Bean } \\
\text { VC }(20 \%)\end{array}$ & \multicolumn{5}{|c|}{ Yard Long Bean } \\
\hline TC $(20 \%)$ & $158.12 \mathrm{~b}$ & $16.33 \mathrm{a}$ & $14.12 \mathrm{~b}$ & $9.78 \mathrm{a}$ & $28.79 \mathrm{a}$ \\
\hline FP & $84.53 \mathrm{c}$ & $10.45 \mathrm{~b}$ & $6.08 \mathrm{c}$ & $9.60 \mathrm{ab}$ & $21.56 b$ \\
\hline
\end{tabular}

Means followed by the same letters are not significantly different for each treatment means at the 0.05 by LSD,

Table 3: Photosynthesis rate $\left(\mu \mathrm{mol} \mathrm{m} \mathrm{s}^{-2}\right)$ of Bush bean, Winged bean and Yard long bean

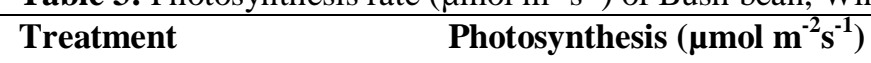

$\begin{array}{lll}\text { Pre flowering stage } & \text { Flowering stage } & \text { Pod formation stage }\end{array}$

\begin{tabular}{llll}
\hline Bush Bean & $28.83 \mathrm{a}$ & $34.67 \mathrm{a}$ & $45.22 \mathrm{a}$ \\
VC $(20 \%)$ & $27.78 \mathrm{a}$ & $33.33 \mathrm{a}$ & $44.08 \mathrm{a}$ \\
TC $(20 \%)$ & $25.33 \mathrm{~b}$ & $30.50 \mathrm{~b}$ & $39.56 \mathrm{~b}$ \\
FP & & & \\
Winged Bean & $28.78 \mathrm{a}$ & $51.89 \mathrm{a}$ & $56.17 \mathrm{a}$ \\
VC $(20 \%)$ & $28.67 \mathrm{a}$ & $50.78 \mathrm{a}$ & $53.89 \mathrm{~b}$ \\
TC $(20 \%)$ & $21.61 \mathrm{~b}$ & $34.89 \mathrm{~b}$ & $42.89 \mathrm{c}$ \\
FP & & \\
Yard Long bean & $17.44 \mathrm{a}$ & $30.33 \mathrm{a}$ & $32.22 \mathrm{a}$ \\
VC $(20 \%)$ & $17.83 \mathrm{a}$ & $28.67 \mathrm{a}$ & $31.22 \mathrm{a}$ \\
TC $(20 \%)$ & $15.83 \mathrm{~b}$ & $25.22 \mathrm{~b}$ & $27.89 \mathrm{c}$ \\
FP & & & \\
\hline
\end{tabular}

Means followed by the same letters are not significantly different for each treatment means at the 0.05 by LSD, 
Table 4: Fresh Yield $\left(\right.$ ton $\left.\mathrm{ha}^{-1}\right), \% \mathrm{~N}$ in mature pod, Protein $(\mathrm{g} / 100 \mathrm{~g})$ in mature pod of Bush bean, Winged bean and Yard long bean

\begin{tabular}{|c|c|c|c|c|}
\hline Treatment & $\begin{array}{l}\text { Fresh } \\
\left(\text { ton }^{-1} \mathbf{h}^{-1}\right)\end{array}$ & Yield & $\% \mathrm{~N}$ in mature pod & Protein $(\mathrm{g} / \mathbf{1 0 0 g})$ in mature pod \\
\hline \multicolumn{5}{|l|}{ Bush Bean } \\
\hline VC $(20 \%)$ & $2.98 \mathrm{a}$ & & $4.24 \mathrm{a}$ & $26.50 \mathrm{a}$ \\
\hline TC $(20 \%)$ & $1.45 \mathrm{~b}$ & & $3.08 \mathrm{~b}$ & $19.23 \mathrm{~b}$ \\
\hline FP & $0.83 \mathrm{c}$ & & $3.06 \mathrm{~b}$ & $19.11 \mathrm{~b}$ \\
\hline \multicolumn{5}{|l|}{ Winged Ben } \\
\hline VC $(20 \%)$ & $7.28 \mathrm{a}$ & & $3.53 \mathrm{a}$ & $22.04 \mathrm{a}$ \\
\hline TC $(20 \%)$ & $5.06 \mathrm{~b}$ & & $3.19 \mathrm{~b}$ & $19.91 \mathrm{~b}$ \\
\hline FP & $2.97 \mathrm{c}$ & & $3.02 \mathrm{~b}$ & $18.86 \mathrm{~b}$ \\
\hline \multicolumn{5}{|c|}{ Yard Long Bean } \\
\hline VC $(20 \%)$ & $2.22 \mathrm{a}$ & & $3.96 \mathrm{a}$ & $24.74 \mathrm{a}$ \\
\hline TC $(20 \%)$ & $1.58 \mathrm{~b}$ & & $3.73 \mathrm{~b}$ & $22.04 \mathrm{~b}$ \\
\hline FP & $0.85 \mathrm{c}$ & & $3.50 \mathrm{~b}$ & $21.84 \mathrm{~b}$ \\
\hline
\end{tabular}

Means followed by the same letters are not significantly different for each treatment means at the 0.05 by LSD,

\section{DISCUSSION}

This study has shown that the total biomass and dry biomass of the three legumes, namely bush bean, winged bean and yard long bean varied significantly under the three different treatments, consisting of VC (20\%), TC (20\%) and farmer's practice (FP) or control. VC (20\%) and TC (20\%) treatments had a beneficial optimistic effect on total biomass and dry biomass of the three legumes. VC (20\%) was found to be the most effective for increasing the total and dry biomass in all the three legumes (Table 1). Roy et al. (2010) observed similar results with Phaseolus vulgaris a bush bean plant. Manivannan et al. (2009) and Valdez-Perez et al. (2011) also reported a significant increase was observed in total shoot, root and pod biomass and total shoot, root and pod dry biomass of the three legumes in VC (20\%) treatment compared to TC (20\%) treatment and control or FP.

The total height of the three legumes also varied significantly in the different VC (20\%), TC (20\%) and farmers practice treatments (Table 1). Roy et al. (2010) and Singh and Chauhan (2009) also reported similar results in bush bean. Furthermore Valdez-Perez et al. (2011) and Manivannan et al. (2009) reported that root and shoot length of bush bean (Phaseolus vulgaris) was higher in vermicompost treatment than in the other treatments. As shown in Table 1, the total height of bush bean, winged bean and yard long bean was significantly higher in the VC $(20 \%)$ treatment compared to TC (20\%) and FP treatments. Singh and Chauhan (2009) also found the similar result in legume. Roy et al. (2010) reported that the highest plant height for Zea mays was in the compost plots, but in the case of legumes the highest plant height was observed in vermicompost plots. It has been suggested that probably vermicompost added humic acid to the soil which subsequently enhanced plant growth (Arancon et al. 2003).

According to Manivannan et al. (2009) and Singh and Chauhan (2009), working with legumes, the number of nodules was highest in vermicompost treatment than in compost, control and $\mathrm{N}: \mathrm{P}: \mathrm{K}$ treatments. As can be seen in Table 1, in the present study, the number of nodules in bush bean, winged bean and yard long bean was also observed to be significantly higher in the VC $(20 \%)$ treated plants (Table 1 ).

With regard to pod weight, the three legumes showed significant differences when treated with VC (20\%), TC (20\%) and FP (Table 2). Manivannan et al. (2009) reported that pod weight in the bush bean (Phaseolus vulgaris) was higher in vermicompost treatment than those of control and N:P:K fertilizer treatments. Singh and Chauhan (2009) also observed that pod number in the bush bean (Phaseolus vulgaris) varied significantly with the application of vermicompost, compost and apposite amounts of $\mathrm{N}: \mathrm{P}: \mathrm{K}$ (control). In the present study, the number of pod in bush bean and winged bean showed similar results but some contradiction was 
observed in the case of yard long bean. In yard long bean VC (20\%) and TC (20\%) treatments did not show any significant increase in pod number per plant but were significantly different when compared to FP (Table 2). Edwards (1995) and Lalljee (2006) also reported that in vermicompost treatment, pod dry weight of the legumes was significantly higher than in plants from compost and farmer's practice treatments.

In the case of pod length both bush bean and yard long bean, did not vary significantly between VC (20\%) and TC (20\%) treatment but was significantly lower in FP treatment. However pod length in winged bean varied significantly when grown with VC (20\%), TC (20\%) and FP treatments (Table 2). Manivannan et al. (2009) reported similar observations showing that pod length in bush bean (Phaseolus vulgaris) was higher in vermicompost treatment than in control and N:P:K fertilizer treatments. Contrary to the above observations, Shehata and El-Helaly (2010) reported that pod length in bush bean (Phaseolus vulgaris) when treated with vermicompost was not significantly different from compost treatment. Similar results were also reported by Shehata et al. (2011).

The photosynthetic rate was significantly affected by the treatment variables. Yard long bean, bush bean and winged bean grown in VC $(20 \%)$ and TC (20\%) exhibited the highest photosynthetic rate at pre flowering, flowering and pod formation stages compared to farmer's practice (FP) (Table 3). Befrozfar et al. (2013) reported similar results. Winged bean grown in VC $(20 \%)$ and TC $(20 \%)$ recorded identical photosynthetic rate at pre flowering and flowering stages while winged bean grown with VC (20\%) showed significantly higher photosynthetic rate at pod formation compared to TC (20\%) treatment. In all the experiments, farmer's practice (FP) treatment recorded the lowest photosynthetic rate. Photosynthesis in all the tested legume vegetables was high up to the pod formation stage. Similar results were observed and reported by Fatima et al. (2011).

With regard to yield, Luqueno et al. (2010), Manivannan et al. (2009) and Joshi et al. (2009) found the highest yield in vermicompost treatment compared to other treatments. Singh and Chauhan (2009) and Luqueno et al. (2010) also reported that yield in bush bean (Phaseolus vulgaris) was significantly different when treated with vermicompost, compost and farmer's practice. Similar results can be seen in Table 4. According to Manivannan et al. (2009), the amount of protein in the pods of bush bean was higher in vermicompost than in control treatment. Similarly in the present study amount of protein in the mature pod was significantly higher in VC (20\%) treatment than in TC (20\%) and FP but no significant difference was observed between TC (20\%) and FP treatments (Table 4). Sheheta et al. (2011) observed similar results in bush bean.

\section{CONCLUSIONS}

In the present study, the three legumes grown with VC (20\%) showed better performance with regard tototal biomass production, plant height, pod number, pod weight, pod length, nodule formation and photosynthetic rate at the different vegetative stages, yield and the amount of protein in mature pods. VC (20\%) also increased the longevity, productivity and flower initiation of in all the three legumes and therefore production was highest in VC $(20 \%)$ treated plants.

\section{ACKNOWLEDGEMENT}

We appreciatively acknowledged the University of Malaya for providing financial support for accomplished the present research (UMRG Grant number: RG253-13AFR).

\section{REFERENCES}

Albiach, R., R. Canet, F. Pomares, and F. Ingelmo (2000). Microbial biomass content and enzymatic activities after the application of organic amendments to a horticultural soil. Biores. Technol., 75: 43-48.

Amira, A., El-Fallal and F.M. Fatma (2003). Metabolic changes in broad bean infected by Botrytis fabae in response to mushroom spent straw. Asian J. of Plant Sci., 2(14):1059-1068.

AOAC (2005). Official Methods of Analysis, 16 th edition. Association of Official Analytical Chemists, Arlington, VA.

Arancon, N.Q., C.A. Edwards, P. Blerman, J.D. Metzger, S. Lee, C. Welch (2003). Effects of vermicomposts on growth and marketable fruits of field-grown tomatoes, peppers and strawberries. Pedobiologia., 47: 731-735.

Baziramakenga, R. and R.R.S. Simard (2001). Effect of de-inking paper sludge compost on nutrient uptake and of snap bean and potatoes grown in rotation. Compost Sci. and Util., 9: 115-126. 
Befrozfar, M.R., D. Habibi, A. Asgharzadeh, M. Sadeghi-Shoae and M.R. Tookalloo (2013). Vermicompost, plant growth promoting bacteria and humic acid can affect the growth and essence of basil (OcimumbasilicumL.). Annals of Biol. Res., $4(2): 8-12$.

Brink, M. and G. Belay (Editors) (2006). Plant Resources of tropical Africa 1. Cereals and Pulses, PROTA Foundation, pp: 150-153. Wageningen, Netherlands/ Backhuys Publishers, Leiden, Netherlands/ CTA, Wageningen, Netherlands.

Cespedes L., M.C., A. Stone and R.P. Dick (2006). Organic soil amendments; impacts on snap bean common root rot and soil quality. Applied Soil Ecol., 31: 199-210.

Diez, T. and M. Krauss (1997). Effect of long-term compost application on yield and soil fertility. Agrobiological Research-Zeitschrift Fur Agrarbiolgie-Agriculturechemie Okologie, Germany, 50: 78-84.

Edwards, C.A. (1995). Historical overview of vermicomposting. Biocycle. 36: 56- 58.

Fatima, T., J.R. Teasdale , J. Bunce and A.K. Mattoo (2011). Tomato response to legume cover crop and nitrogen: differing enhancement patterns of fruit yield, photosynthesis and gene expression. Func. Plant Biol., 39(3): 246-254.

Francis, C.A., and H. Daniel (2004). Organic farming. Encyclopedia of soils in the environment. pp: 77-84. Elsevier, Oxford, UK.

Giusquiani P.L., M. Pagliai, G. Gigliotti, D. Businelli and A. Benetti (1995). Urban waste compost: effects on physical, chemical and biochemical soil properties. J. Environ. Qual., 24: 175-182.

Harvest P. (2006). A review of Agriculture and health policies in Uganda with implications for the dissemination of Biofortified crops. Washington DC: IFPRI

Joshi D., K.S. Hooda, J.C. Bhatt, B.L. Mina, H.S. Gupta (2009). Suppressive effects of composts on soil-borne and foliar diseases of French bean in the field in the western Indian Himalayas. Crop Protec., 28:608-615.

Kara, R., T.J. Dalton, and A.M. Featherstone (2009). A Nonparametric Efficiency Analysis of Bean Producers from North and South Kivu.Prepared for the Southern Agricultural Economics Association Annual Meeting, Atlanta, Georgia.

Lalljee, B. (2006). Effects of two commercially available composts on soil properties, yield and mineral content of bean (Phaseolus vulgaris). Revue Agricole et Sucriere de l'Ile Maurice., 85: 75-83.

Luqueno, F.F., V. Reyes-Varela, C. Martinez-Suarez, G.Salomon-Hernandez, J.Yanez-Meneses, J.M. Ceballos-Ramirez, L. Dendooven (2010). Effect of different nitrogen sources on plant characteristics and yield of common bean (Phaseolus vulgaris L.). Bioresour. Technol., 101: 396-403.
Mäder, P., A. Fliessbach, D. Dubois, L. Gunst, P. Fried, and U. Niggli (2002). Soil fertility and biodiversity in organic farming. Sci., 296:1694-1697.

Manivannan, S., M. Balamurugan, K. Parthasarathi, G.Gunasekaran and L.S. Ranganathan (2009). Effect of vermicompost on soil fertility and crop productivity-bean (Phaseolus vulgaris). J. Environ. Biol., 30 (2): 275-281.

Marlene, A.S. and I.F.M. Válio (1996), Influence of Staking on Development of Winged Bean Plants. R. Bras. Fisiol. Veg., 8(2):99-103.

Pagliai, M., N. Vignozzi, and S. Pellegrini (2004). Soil structure and the effect of management practices. Soil Till. Res., 79:131-143.

Rahman, M.M., M. Sofian-Azirun and A.N. Boyce (2013). Response of nitrogen fertilizer and legumes residues on biomass Production and utilization in rice-legumes rotation. The J. of Animal \& Plant Sci., 23(2): 589-595.

Roy, S., K. Arunachalama, B.K. Dutta and A. Arunachalam (2010). Effect of organic amendments of soil on growth and productivity of three common crops viz. Zea mays, Phaseolus vulgaris and Abelmoschus esculentus. Appl. Soil Ecol., 45: 78-84.

Shannon, D., A.M. Sen, and D.B. Johnson (2002). A comparative study of the microbiology of soils managed under organic and conventional regimes. Soil Use Manage., 18:274-283.

Shehata, S.A., Y.M. Ahmed, A. Emad, Shalaby and O.S. Darwish (2011). Influence of Compost Rates and Application Time on Growth, Yield and Chemical Composition of Snap Bean (Phaseolus vulgaris L). Aus. J. of Basic and Applied Sci., 5(9): 530-536.

Shehata, S.A. and M.A. El-Helaly (2010). Effect of compost, humic acid and amino acid on yield of snap beans. J. of hort. Sci. and orn. Plants., 2(2): 107-110.

Singh N.I. and J.S. Chauhan (2009). Response Of French Bean (Phaseolus Vulgaris L.) To Organic Manures And Inorganic Fertilizer On Growth \& Yield Parameters Under Irrigated Condition. Nat. and Sci., 7(5):1-3.

Takahashi, K. (1981). Physiological disorders in Chinese cabbage. pp: 225-233. N.S. Talekar and T.D. Griggs (eds.). Chinese cabbage. AVRDC, Shan hua, Taiwan.

Thy, S. and P. Buntha (2005). Evaluation of fertilizer of fresh solid manure, composted manure or biodigester effluent for growing Chinese cabbage (Brassica pekinen-sis). Livestock Res. Rural Dev., 17(3):149154.

Wells, A.T., K.Y. Chan, P.S. Cornish (2000). Comparison of conventional and alternative vegetable farming systems on the properties of a yellow earth in New South Wales. Agril. Ecos. and Environ., 80: 4760.

Yanagy, S.O. (1983). Proper ties of the winged bean, (Psophocarpus tetragonolobus) protein in 
comparison with soybean (Glycine max) and common bean (Phaseolus vulgaris) protein. Agril. and Biol. Che., 47:2273-2280.

Valdez-Perez, M.A., F. Fernandez-Luqueno, O. FrancoHernandez (2011). Cultivation of beans (Phaseolus vulgaris) in limed or unlimed wastewater, sludge, vermicompost or inorganic amended soil. Scientia Hort., 128:380-387.

Vogtmann, H., K.Fricke and T. Turk (1993). Quality, physical characteristics, nutrient content, heavy metaIs and organic chemicals in biogenic waste campost. Campost Sci.Uti., 4:69-87.

Received: June 15, 2016; Accepted: June24, 2016 